\title{
Overview and Analysis of Industry in Vietnam under Taiwan's Southbound Policy
}

\author{
Tzu-Yi YANG ${ }^{1}$ \\ Nguyen Phuc NGUYEN ${ }^{2}$ \\ Wen-Chuan $\mathrm{FU}^{3}$ \\ Chia-Jui PENG ${ }^{4}$
}

\begin{abstract}
Taiwan proposes southbound policy from 1993 until now. But this policy doesn't tell which industries are suitable for entering into each country? Also, Taiwan was ranked number one to investment Vietnam from 2001 to 2006. Therefore, this research uses regression model to analyze which industries are currently suitable for investment in Vietnam. The research period is from January 052009 to October 01 2019, and the research results show that the appropriate industries are slightly from Ho Chi Minh and Hanoi markets.
\end{abstract}

KEYWORDS: Hanoi Market, Ho Chi Minh Market, Southbound Policy, Vietnam.

JEL CLASSIFICATION: D22, D04, L69, L79

\section{INTRODUCTION}

In 1990s, Taiwan was in its booming stage, its government promoted southbound diplomacy and economic policy aggressively, however, the result was not quite good, today, the government promoted again its new southbound policy, and the implementation targets included Vietnam, Singapore and Southeast Asia. Statement from National Development Council (2010) mentioned that ever since the start of opening-up policy of Vietnam economy to the outside after the end of 1986, it has invited enterprise and investment to its country from the outside. In the period from 2001 to 2006 when the infrastructure of Vietnam was gradually set up, the investment from foreign investors was heated up continuously. In the period from 1988 to 2006, the accumulated investment from other countries in Vietnam reached 60.62 billion US dollars, wherein Taiwan has invested 8.26 billion US dollars with a share about $13.62 \%$, which ranked number one around the world. In 2007, It was a very important year to Vietnam, and it was the second year for Vietnam to realize its economicsocial development goal for the period from 2006 to 2010, and it was also the first year for Vietnam to join the World Trade Organization. Therefore, Vietnam was one of the countries with the highest development potential, a statement from IP Observer - Patent \& Trademark News from NAiP (2018) said: The economy situation of Vietnam was on a rising trend, and its domestic "labor population reached almost 70\%", meanwhile, its geographical location was quite good, therefore, many countries around the world wanted to enter Vietnam market before it was fully developed, and Taiwan of course was included in it.

The GDP of Vietnam before 1992 was unstable, however, after financial tsunami in 1993 and

\footnotetext{
${ }^{1}$ Ming Chi University of Technology, Taiwan, tyyang@mail.mcut.edu.tw

${ }^{2}$ University of Economics, The University of Danang, Vietnam, nguyennp@due.edu.vn

${ }^{3}$ Chung Yuan Christian University, Taiwan, chyuan650731@cycu.org.tw

${ }^{4}$ Chung Yuan Christian University, Taiwan, pcrabao@gmail.com.
} 
economic reform, its GDP rose gradually, and in 2009 its GDP broke through 10 trillion US dollars, and Dantri.com.vn (2009) said: "at that moment, Vietnam government has proposed economic promotional policies such as favored loaning interest rate, tax reduction and investment capital easing policy to help the industry to surpass the financial crisis". Today, Vietnam still belonged to developing country, and it will rely more on the importing business, and will be easily affected by foreign investors, the main fluctuation of domestic GDP was affected by the production capacity of plants of foreign investors. SWCW (2017) said, "GDP growth of this country of 2017 was $6.81 \%$, which was higher than the target of $6.7 \%$ made by the government, and was also superior to $6.21 \%$ of 2016 ", which was as shown in Figure 1.

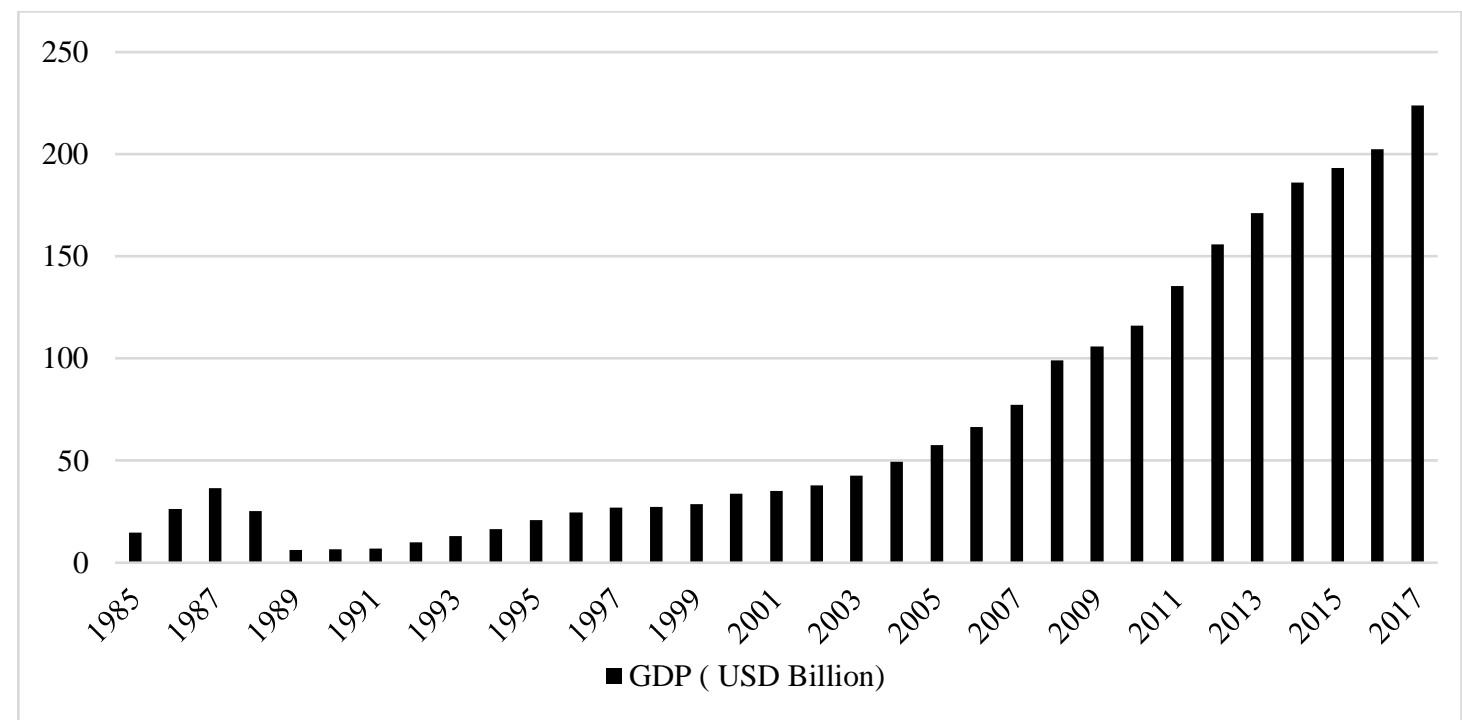

Figure 1. Vietnam's GDP index

Source: Trading Economics (2018), The World Bank (2018) and data arranged by this group

Figure 2 showed that the quarterly economic growth rate of 2016 was lower than that of 2015, for example, in the first quarter of 2015 , it dropped from $6.12 \%$ to $5.48 \%$ in 2016 ; and in the second quarter, it dropped from $6.47 \%$ to $5.78 \%$; and in the third quarter, it dropped from $6.87 \%$ to $6.56 \%$; and in the fourth quarter, it dropped from $7.01 \%$ to $6.68 \%$; according to a report from vietnamplus.vn (2016), in 2016, Vietnam had faced lots of challenges, for example, the rise of inflation, the rise of medical and educational service price, the rise of agricultural product, the reduction of its attraction of cheap labor and over-reliance on FDI enterprises; therefore, the economy of Vietnam in 2016 was unstable.

From 2016 to 2018, the quarterly economic growth rate rose gradually, according to a report from SWCW (2017), it showed that 2017 average economic growth rate for Vietnam was $6.73 \%$, which was the greatest rise for the nearest one decade, and it was mainly brought up by forestry and sea food industries, etc. 


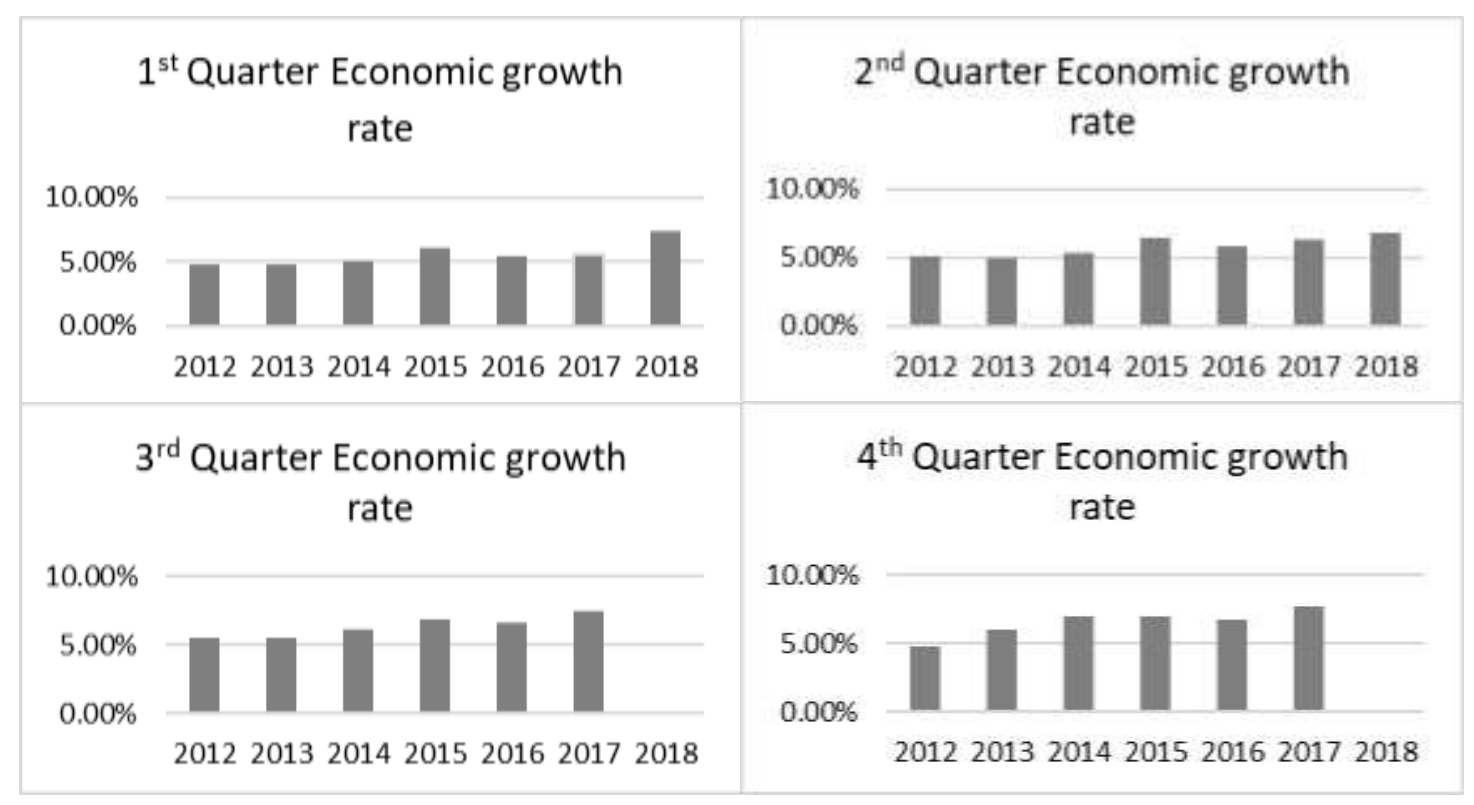

Figure 2. The quarterly economic growth rate from 2012 to 2018

Source: From Stock-ai.com and as arranged by this group

Presently, Vietnam government had spent lots of efforts in improving domestic commercial field and in promoting the development of other industries, meanwhile, NOWNEWS (2018) pointed out that "Vietnam was full of labor, its cost was quite low, and these were advantages for attracting the foreign investors, however, labor here only possessed low skill, and it's the major barrier for foreign investor to invest Vietnam, the related departments of Vietnam needed to improve it with lots of efforts". According to lots of data, it was pointed out that Vietnam had great potential and advantage, plus the opinion proposed by Boubakari et al. (2010) that stock market indeed will affect the economic growth and the same conclusion proposed by Levine and Zervos (1996a), they all pointed out that the fluidity of stock market will have positive and significant correlation to the present and future economic growth rate. In later 1980s, due to the steep rise of trade relationship between this country and Mainland China, in order to pursue economic stability and safety, this country has proposed in 1993 "work guidelines for strengthening the economic and trading relationship with southeast Asia area", and on Jan. 01, 1994, it has formally become "southbound policy", such policy can be divided into three stages from 1994 to 2003 as shown in Table 1, and Kao (2005) said: For the first stage in 1994, this country has proposed for the first time and promoted the southbound policy, and work guideline for strengthening the economic and trading relationship with southeast Asia area have been prepared, its main contents included helping domestic enterprises to move products to southeast Asia for production to increase the employment opportunity of southeast Asia countries, and encouraging Taiwan's enterprise to invest in southeast Asia and strengthening the economic and trading relationship with southeast Asia. The second stage was in 1997, this country has used the opportunities of financial crisis and economic difficulty in southeast Asia to re-propose the promotion of southbound policy, hopefully, while stopping Taiwan's enterprise in investing Mainland China, using this opportunity to developing real relationship with southeast Asia, "work guidelines for strengthening economic and trading relationship with southeast Asia, Australia and New Zealand area" was approved on May of the same year, the implementation target was expanded to The Republic of the Union of Myanmar, Laos and Australia and New Zealand. Although there was financial crisis in 1997 in East Asia, yet the economic vision in Vietnam 
was still good, therefore, in 1998, Taiwan government has proposed "action project for strengthening the promotion of economic and trading cooperation with southeast Asia", including the relief of financing difficulty of Taiwan's enterprises and the strengthening of investment in southeast Asia through international financial cooperation and the enhancement of financial stability.

Wang (2002) has pointed out that in the third stage of implementation of southbound policy, the willingness of participation from the enterprise was not high, meanwhile, if the government wanted Taiwan's enterprise to go to southeast Asia to invest, it should make local market evaluation first, if prior evaluation was not made, the investment risk will be enhanced, therefore, many entrepreneurs hesitated to invest; meanwhile, Taiwan Chamber of Commerce (2017) emphasized: new southbound policy was not to follow "the Belt and Road Initiative", it was not as simple as "who went there for investment, you followed for investment", because, this could easily form the Portuguese egg tart effect, in other words, the so-called phenomenon of a swarm of bees. The investors must calm down to think "What does the country need? And investment in what country will show our competitive advantages?"

Table 1. Southbound policy development overview

\begin{tabular}{|c|c|c|}
\hline $\begin{array}{l}1993 \text { The southbound policy } \\
\text { from the President Teng-Hui } \\
\text { Li }\end{array}$ & $\begin{array}{l}2002 \text { President Shui-Bian } \\
\text { Chen re-started the } \\
\text { southbound policy }\end{array}$ & $\begin{array}{l}2016 \text { President Ing-Wen } \\
\text { Tsai's new southbound } \\
\text { policy }\end{array}$ \\
\hline $\begin{array}{l}\text { - The idea of new southbound } \\
\text { policy started from the } \\
\text { beginning of } 1993 \text {. } \\
\text { - } \text { First stage was } 1994-1996 \\
\text { - } \text { In 1994, work guidelines for } \\
\text { strengthening economic and } \\
\text { trading cooperation with } \\
\text { Southeast Asia area were } \\
\text { prepared. } \\
\text { The second stage was } 1997- \\
\text { 1999 } \\
\text { In } 1997, \text { action project for } \\
\text { strengthening economic and } \\
\text { trading cooperation with } \\
\text { southeast Asia was } \\
\text { approved. }\end{array}$ & $\begin{array}{l}\text { - The third stage was } \\
\text { - In 2000-2003 } \\
\text { policy was started again } \\
\text { to encourage Taiwan's } \\
\text { investors to invest in } \\
\text { Southeast Asia. } \\
\text { - Strengthen Taiwan's } \\
\text { enterprises in southeast } \\
\text { Asia to invest in } \\
\text { financial supporting } \\
\text { system } \\
\text { Decided to strengthen } \\
\text { the signing of free trade } \\
\text { agreement with } \\
\text { important countries }\end{array}$ & $\begin{array}{l}\text { - In } 2015, \text { new southbound } \\
\text { policy was proposed, and } \\
\text { the goal was to strengthen } \\
\text { the overall relationship } \\
\text { with Southeast Asia and } \\
\text { East Asia. } \\
\text { - In } 2016, \text { new southbound } \\
\text { policy guidelines were } \\
\text { announced. } \\
\text { - Bilateral investment and } \\
\text { tourism was promoted. } \\
\text { - Human resource and } \\
\text { cultural exchange was } \\
\text { strengthened. } \\
\text { - In } 2017 \text {, five flagship } \\
\text { projects and three potential } \\
\text { fields were prepared and } \\
\text { promoted. }\end{array}$ \\
\hline
\end{tabular}

Source: Kao (2005), news release of People First Party (2016), as arranged by Chou (2016) this group

Liu and Tu (2009) had studied the correlation and volatility between the stock market and macro economy in US, and it was proved that stock market was the window of economy, that is, stock market was the leading index of prosperity of a country, and the leading index can predict future prosperity and economic development, therefore, in this study, empirical study will be conducted on the stock market of Vietnam to analyze related industries that were suitable to be invested in Vietnam market. 


\section{LITERATURE REVIEW}

Economic development was a process for stable growth of real income of each person in a country, and the contents included the increase of income of national of a country, the solid social welfare system and even distribution of income, etc. And its final goal was to enhance the quality of life of citizens in a country. Mehl (2009) had studied that the yield difference and stock yield were predicting factors of economic growth, and the research area included G7 countries and newly emerging Asia countries, and also included US, Canada, England, France, Germany, Italy, Japan, Korea, Singapore, Malaysia, Thailand and Taiwan. It was pointed out that the change of stock price can reflect and predict the change of economic growth. Of course, the relationship between stock price and economic growth was not only proved in this study, Bank of Valletta Review (2007) had also studied the relationship between international stock market and the economy, and the stock markets of 10 worldwide stock markets, for example, US, England, Japan, Germany and France were taken as research targets to investigate, for a long term, if the stock market will affect the rise or fall of Gross Domestic Product (GDP), and in this study, Granger causality test was adopted, and the result showed that stock price will indeed affect GDP, and one-way causality relationship existed between stock price and GDP.

Macro-economic index was to use marked number such as economic growth, consumption, investment, export and trading of a specific area to analyze its economic activity situation. They included industrial production index, consumer price index, money supply and exchange rate; and Chang K. L. (2009) had used economic cycle to study the relationship between stock market and macro economy; and economic cycle can be divided into classic cycle and growth cycle, classic cycle was the fluctuation of economic activity level, and growth cycle was the cycle fluctuation of macro economy activity with the removal of long term trend; the macroeconomic variables included real GDP, employment, total value of importing and exporting trading and the sale revenue of production industry, etc.; meanwhile, the "monthly data" of Taiwan in the period from Feb. 1975 to Feb. 2005 were analyzed, after it was conducted with Pearson correlation test and test, the result showed that stock market was leading index to real GDP, employment, total value of importing and exporting trading and sale revenue of production industry, in other words, stock market had close relationship to the economic development of a country.

The higher the fluidity of a stock market, the higher the trading activity of stock and the corresponding trading volume; according to the study made by $\mathrm{Su}$, Lowe, Yuan and Yang (2016), it was pointed out that the future macro-economic cycle will be affected by the overall fluidity of Taiwan's stock market, which meant that Taiwan's stock market was a leading index. In the study, Granger causality test was used to prove that the overall fluidity of stock market of Taiwan will have forecasting power to the future macro-economic cycle, furthermore, it was pointed out from time series and regression result that fluidity of stock market will have positive effect to stock market yield, volatility of stock market yield and interest rate of commercial paper; when the fluidity of stock market of the previous quarter was reduced, then the macro prosperity of this quarter will show a decline phenomenon, on the contrary, if the fluidity was enhanced, then the macro prosperity of this quarter will be on a growth; this result showed that the fluidity of Taiwan's stock market will indeed affect future economic development; however, not only the fluidity of Taiwan's stock market was related to economic development, Levine(1991) and Bencivenga et al. (1995) thought that stock market mainly used fluidity of stock to exploit its aggressive action in the economic growth, therefore, the fluidity of stock can facilitate the economic growth.

Demirguc-Kunt et al. (1996) had investigated if in stock market, the economic activity can be affected through the creation of fluidity, and the research period was from 1976 to 1993 . The 
fluidity of stock market was evaluated according to the ratio between commercial trading value and GDP of 1976, therefore, fluidity can be classified into four types, which were highly insufficient of fluidity (1.4: Countries with highly insufficient of fluidity included Chile, Denmark, Greece, Jordan, Luxembourg, Nigeria, Norway, Portugal, Venezuela), insufficient of fluidity (2.2: Countries with insufficient of fluidity included Austria, Belgium, Columbia, Finland, Indonesia, Malaysia, Mexico, Spain, Sweden and Zimbabwe), normal fluidity (2.4: Countries with normal fluidity included Australia, Brazil, Canada, France, Germany, Netherlands, Singapore, Thailand, England and USA) and very high fluidity (3.4: Countries with high fluidity included Argentina, Hong Kong, India, Israel, Italy, Japan, Korea, Philippine and Taiwan), and the result showed that a country with higher fluidity will have higher growth of GDP per capita per person, which was as shown in Figure 3.

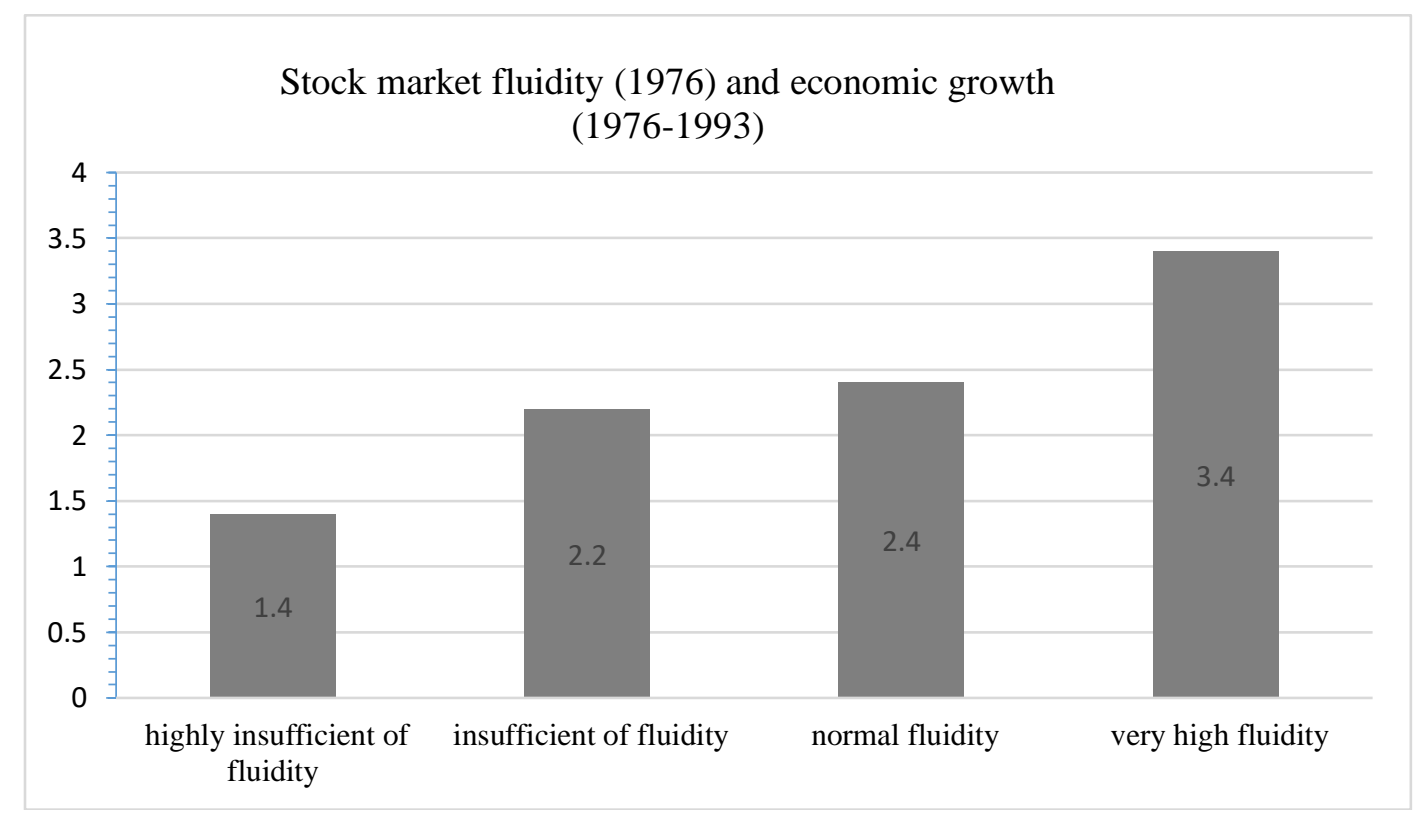

Figure 3. Stock market fluidity (1976) and economic growth (1976-1993) Source: As arranged by Demirguc-Kunt et al. (1996) and this group

For countries with high varied transaction volatility of stock market in 1976, its growth speed in 1993 was higher than that of stable countries, according to Schwert (1989), the volatility of stock market was evaluated using floating standard deviation, and it was defined using the monthly mean value of the rate of return of stock market and 12-months autocorrelation, therefore, volatility can be divided into four types, which were respectively very stable (1.9: Very stable countries included Argentina, Columbia, Denmark, Greece, Norway, Spain, Sweden and Venezuela), stable (1.7: Stable countries included Austria, Belgium, Brazil, Finland, Italy, Mexico and Sweden), varied (1.8: Varied countries included Canada, Chile, France, Germany, India, Jordan and Philippine) and highly varied (2.8; Highly varied countries included Australia, Israel, Japan, Korea, Netherlands, Thailand, England and USA); and the result showed that countries with highly varied volatility will have higher growth of GDP per capita (\%) each year than those of the other three, which was as shown in Figure 4. The research result showed that positive correlation existed between stock market fluidity and economic growth, and in stock market, the economic activity can be affected through the creation of fluidity, the fluidity of stock market can facilitate the prediction of economic growth. 


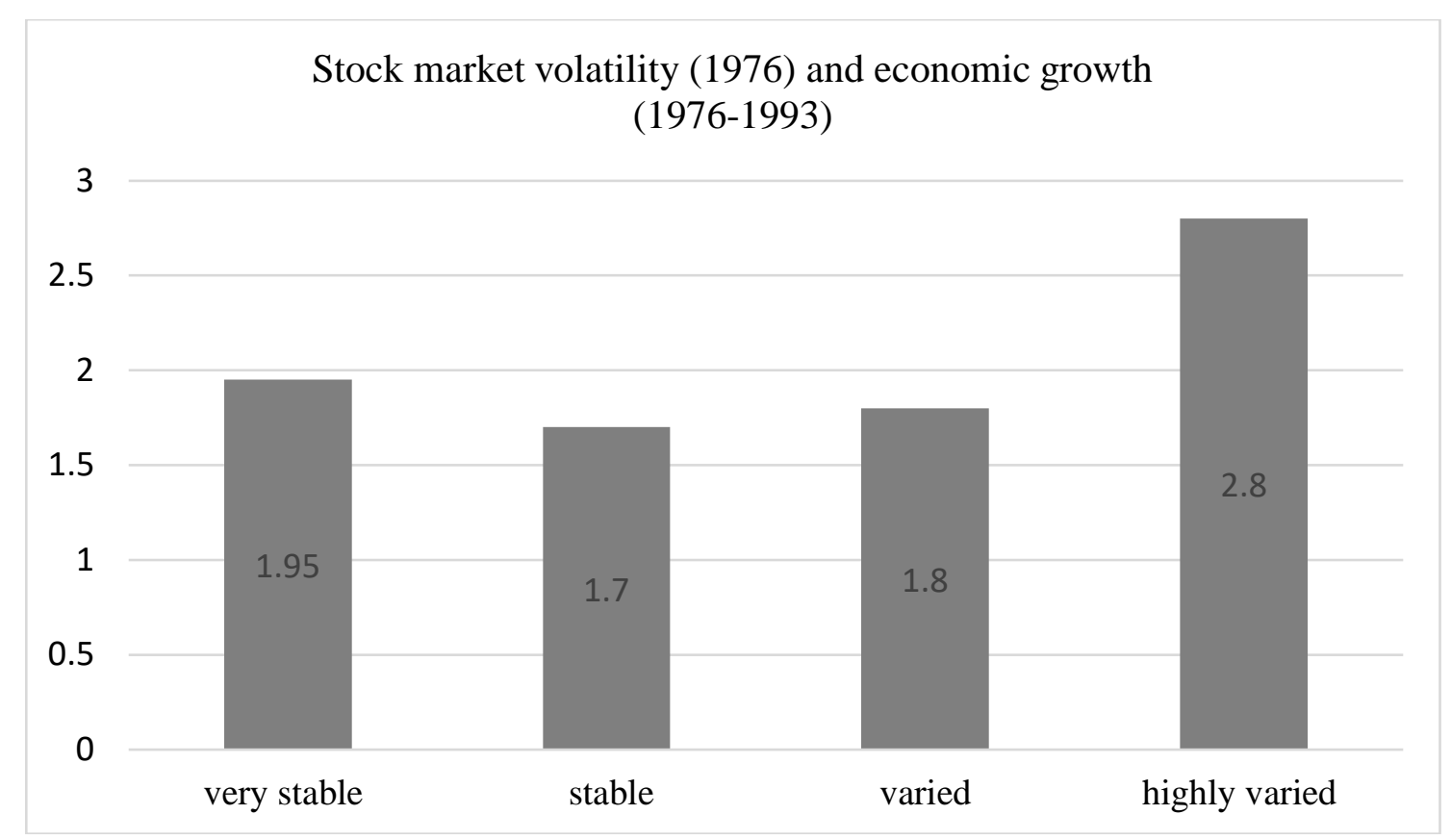

Figure 4. Stock market volatility (1976) and economic growth (1976-1993) Source: As arranged by Demirguc-Kunt et al. (1996) and this group

Demirguc-Kunt et al. (1996) had studied the relationship between stock market development and long term economic growth, and the research period was from 1976 to 1993, and overall and multi-nation time series economic growth regression model was used to analyze the stock market development and economic growth, the research results showed that positive correlation existed between stock market development and economic growth. Nowbutsing and Odit (2009) had studied and analyzed the relationship between stock market and economic growth in the period from 1989 to 2006 for Mauritius (East Africa), and the results showed that, no matter long term or short term, positive relationship usually existed between stock market development and economic growth.

It has been proved in many researches that close relationship exited between stock market and economic growth, and the economic growth of a country was the result of different industrial category in association with individual operation result. Chang C.C. (2009) had studied the OTC (over-the-counter) companies in the electronic industries in the period from 2005 to 2006, and in this study, 8 types of electronic stocks were used as the research targets, and they were respectively CD-R, DRAM, TFT-LCD, IC design, IC packaging and test, IC foundry, passive components and notebook $\mathrm{PC}$, and they were investigated through three standards of mean rate of return of stock price, scale and prosperity change, from the analysis result, it can be seen that stocks that will be affected due to correlation with stock price included CDR , IC packaging, IC design and notebook PC, and notebook PC will also be affected by the scale, however, CDR and IC design will be affected by the change of economic prosperity. Stocks not affected by stock price but were correlated included DRAM, TFT-LCD, IC foundries and passive components, wherein only DRAM and IC foundry will be affected by economic prosperity.

Wang (2014) had studied the rates of return of stocks of different industries in Taiwan's stock market cycle, and the performance of returns of different stocks was observed in association with the holding time (month, quarter, half year and year), and the types of stocks studied included those in cement industry, foods industry, plastic industry, textile industry, electrical and mechanical industry, electrical appliance and cable industry, chemical and biotech and medical industry, chemical industry and biotech and medical industry, glass and ceramic 
industry, paper-making industry, steel industry, rubber industry, automobile industry, electronic industry, semiconductor industry, computer and peripheral equipment industry, optoelectronic industry, electronic component industry, electronic distribution channel industry, other electronic industry, communication and networking industry, information service industry, building material and construction industry, shipping industry, tourism industry, financial industry, trading and department store industry, and oil and electricity and fuel industry, etc., and they come to a total of 30 categories; meanwhile, the research period was from January 2007 to October 2013 for monthly data, and the research results showed that for stocks of foods industry, rubber industry, automobile industry, communication and network industry, tourism industry and trading and general merchandise industry, positive returns can be obtained in different stocks holding time; and all the above mentioned industries were all in the consumer's goods related industries, therefore, it can be seen that consumer's goods industries were less affected by economic development or other factors.

$\mathrm{Ku}$ (2010) had studied the sales momentum of industries, and the focus was on the correlation between individual stock momentum and industry momentum based on unexpected revenue, and it was found that significant individual stock's sales momentum and industry sales momentum did exist. The research period was from January 1994 to December 2011, and the research targets were on the common stocks of listed stocks or OTC stocks in Taiwan Stock Exchange, and the research methods included seasonal random walk model with drift, momentum strategy and paired nested comparison method. Table 2 showed sales momentum of individual stock, for electronic stock of holding of one month, the sale momentum value of original sale was 1.670 , for electronic stock of holding of three months, the sale momentum value of original sale was 1.372, for electronic stock of holding of six months, the sale momentum value of original sale was 1.019, for electronic stock of holding of 12 months, the sale momentum value of original sale was 0.493 ; in the industry sale momentum, for the electronic stock of holding of one month, the sale momentum value of original sale was 0.748 , for the electronic stock of holding of three months, the sale momentum value of original sale was 0.502 , for electronic stock of holding of six months, the sale momentum value of original sale was 0.397 , for electronic stock of holding of 12 months, the sale momentum value of original sale was 0.199 . In the sale momentum of individual stock, for non-electronic of holding of one month, the sale momentum value of original sale was 1.145 , for non-electronic stock of holding of three months, the sale momentum value of original sale was 1.042, for non-electronic stock of holding of six months, the sale momentum value of original sale was 0.761 , for non-electronic stock of holding of 12 months, the sale momentum of original sale was 0.285 ; for industry sale momentum and for non-electronic stock of holding of one month, the sale momentum value of original sale was 0.704 , for non-electronic stock of holding of three months, the sale momentum value of original sale was 0.583 , for non-electronic stock of holding of three months, the sale momentum value of original sale was 0.320 , for non-electronic stock of holding of 12 months, the sale momentum value of original sale was -0.044 . Therefore, it can be found that no matter in electronic stocks and non-electronic stocks, the sales momentum of individual stock was usually higher than sales momentum of the industry, therefore, no matter electronic stocks or non-electronic stocks, the sales momentum of individual stock can always explain most industry momentum effect. 
Table 2. Average return of individual stock sales and industry

\begin{tabular}{|c|c|c|c|c|}
\hline $\begin{array}{c}\text { Holding } \\
\text { Period }\end{array}$ & \multicolumn{2}{|c|}{ Momentum of Individual Stock } & \multicolumn{2}{c|}{ Industry Sale Momentum } \\
\hline & Electronic Stock & $\begin{array}{c}\text { Non-electronic } \\
\text { Stock }\end{array}$ & Electronic Stock & $\begin{array}{c}\text { Non-electronic } \\
\text { Stock }\end{array}$ \\
\hline $\mathbf{1}$ & 1.670 & 1.145 & 0.748 & 0.704 \\
\hline $\mathbf{3}$ & 1.372 & 1.042 & 0.502 & 0.583 \\
\hline $\mathbf{6}$ & 1.019 & 0.761 & 0.397 & 0.320 \\
\hline $\mathbf{1 2}$ & 0.493 & 0.285 & 0.199 & -0.044 \\
\hline
\end{tabular}

Source: $\mathrm{Ku}(2010)$ and as arranged by this group

To summarize, it was proved in many researches that the stock market can reflect the present industry prosperity and the overall economy, and the association of individual industry thus formed the overall economic development, therefore, in this study, starting from the research objective, empirical model will be designed to empirically analyze related industries that are suitable to be deployed in Vietnam market, and it is believed that this will be the best response to the promotion of new southbound policy by this government.

\section{RESEARCH METHODOLOGY}

\subsection{Data description}

The stock market of Vietnam can be divided into Hanoi Stock Exchange (HNX) and Ho Chi Minh Securities Trading Center (HOSTC). The dependent variables of this study were respectively the trading volume of Hanoi and Ho Chi Minh City, in dependent variables were respectively the trading volume of Hanoi industry stock and Ho Chi Minh industry stock, and the research period was from Jan. 052009 to October 01 2019, and data structure was of daily data, and all the variables were from FiinPro platform (FiinPro). FiinPro was founded in 2008, and it was a leading provider in banking data, commercial information, industrial research and other excellent services in Vietnam. It has set up all kinds of data and analysis platform, including stocks and bond. That company was presently shareholding company, mutual fund management company, bank, financial company and insurance company for local Vietnam and foreign banking institutes, and it also provided services to global institute investors, and this platform contained highly standardized corporate data of more than 3000 listed companies in Vietnam, and the platform also contained macro-economic data, banks and monetary market data, industrial data, secondary transaction data, financial news, merger and acquisition and IPO data; and the database has high credibility too.

The Stock Exchange of Vietnam can be divided into Hanoi and Ho Chih Minh, and the classification was quite consistent, and they can be divided into consumer industry, financial industry, banking industry, production industry, raw material industry, petroleum and natural gas industry, information technology service industry and medical nursing industry, and they came to a total of 8 categories as shown in table 3. 
Table 3. Table of industry categories of listed companies of Hanoi and Ho Chih Minh Stock Exchange

\begin{tabular}{|l|l|l|}
\hline Consumer Industry & Financial Industry & Banking Industry \\
\hline Production Industry & Raw Material Industry & $\begin{array}{l}\text { Petroleum and Natural Gas } \\
\text { Industry }\end{array}$ \\
\hline $\begin{array}{l}\text { Information Technology } \\
\text { Service Industry }\end{array}$ & Medical Nursing Industry & \\
\hline
\end{tabular}

Source: HOSTC (2016) and HNX (2019) and as arranged by this group

\subsection{Empirical model}

This group has used Vietnam stock market to analyze the correlation of industries in Vietnam, and the research period was from Jan. 052009 to October 01 2019, and the data structure was of daily data, to adapt to this study, this group has changed variable structure, and dependent variable and independent variable was changed into rate of change, which was as in formula (1) and formula (2), in this study, in accordance with literature, empirical analysis method that was appropriate to this group was found out as shown in formula (3).

$$
i V R_{(t)}=\frac{i V_{(t)}-i V_{(t-1)}}{i V_{(t-1)}}
$$

Wherein $i V R_{(t)}$ represented rate of change of total trading volume of $(t)$ term of $i$ stock market (Ho Chih Minh, Hanoi), $i V_{(t)}$ represented total trading volume of $(t)$ term of $i$ stock market (Ho Chih Minh, Hanoi), $i V_{(t-1)}$ represented total trading volume of $(t-1)$ term of $i$ stock market (Ho Chih Minh, Hanoi), and $t$ was date.

$$
j V R_{(t)}=\frac{j V_{(t)}-j V_{(t-1)}}{j V_{(t-1)}}
$$

$j V R_{(t)}$ represented the rate of change of total trading volume of $(t)$ term of $j$ industry stock, $j V_{(t)}$ represented total trading volume of $(t)$ term of $j$ industry stock, $j V_{(t-1)}$ represented total trading volume of $(t-1)$ term of $j$ industry stock, $t$ was the date.

$$
\begin{gathered}
i V R_{(t)}=\beta_{0}+\beta_{1} \operatorname{CoR}_{(t)}+\beta_{2} F i R_{(t)}+\beta_{3} \operatorname{BaR}_{(t)}+\beta_{4} \operatorname{InR}_{(t)}+\beta_{5} M a R_{(t)}+\beta_{6} U t R_{(t)}+\beta_{7} T e R_{(t)}+ \\
\beta_{8} M e R_{(t)}+\varepsilon_{(t)}-(3)
\end{gathered}
$$

$\operatorname{CoR}_{(t)}$ represented the rate of change of total trading volume of $(t)$ term of consumer industry, $F i R_{(t)}$ represented rate of change of total trading volume of $(t)$ term of financial industry, $\mathrm{BaR}_{(t)}$ represented rate of change of total trading volume of $(\mathrm{t})$ term of banking industry, $\operatorname{In} R_{(t)}$ represented rate of change of total trading volume of $(t)$ term of production industry, $\operatorname{MaR}_{(t)}$ represented the rate of change of total trading volume of $(t)$ term of raw material industry, $U t R_{(t)}$ represented rate of change of total trading volume of $(t)$ term of petroleum and natural gas industry, $\operatorname{TeR}_{(t)}$ represented the rate of change of total trading volume of $(t)$ term of information technology service industry, $M e R_{(t)}$ represented rate of 
change of total trading volume of $(t)$ term of medical and nursing industry, $\beta_{0}, \beta_{1}$, $\beta_{2}, \beta_{3}, \beta_{4}, \beta_{5}, \beta_{6}, \beta_{7}, \beta_{8}$ were coefficients, $\boldsymbol{\varepsilon}_{t}$ represented error value, and $t$ was date.

\section{EMPIRICAL ANALYSIS}

\subsection{Descriptive statistics}

The results of table 4 showed that the maximal value of rate of change of trading volume of stock market of Ho Chih Minh appeared in the information technology service industry (70.0153), and the minimal value of rate of change of trading volume appeared in medical nursing industry (-0.9785), and the maximal value of standard deviation of rate of change of trading volume appeared in information technology service industry (1.8214). For the Hanoi stock of table 5, it was clear that the minimal value of rate of change of trading volume appeared in the raw material industry (-3.0243), and the maximal value of rate of change of trading volume appeared in the medical nursing industry (953.5864), the maximal value of standard deviation of rate of change of trading volume appeared in the medical nursing industry (20.7151).

Table 4. Descriptive statistics of Ho Chih Min

\begin{tabular}{|l|l|l|l|l|}
\hline & Max. & Min. & Avg. & SDV \\
\hline HoseR & 4.8865 & -0.7865 & 0.0367 & 0.2981 \\
CoR & 6.4664 & -0.8536 & 0.0632 & 0.4218 \\
\hline FiR & 7.0730 & -0.8754 & 0.0680 & 0.4409 \\
\hline BaR & 30.7663 & -0.9670 & 0.2342 & 1.2283 \\
\hline InR & 1.9894 & -0.6856 & 0.0423 & 0.3101 \\
\hline MaR & 2.2553 & -0.7146 & 0.0491 & 0.3351 \\
\hline UtR & 20.2114 & -0.9529 & 0.1319 & 0.8168 \\
\hline TeR & 70.0153 & -0.9599 & 0.2581 & 1.8214 \\
\hline MeR & 47.0747 & -0.9785 & 0.2613 & 1.5522 \\
\hline
\end{tabular}

Note: HoseR: Rate of change of trading volume of Ho Chih Minh, CoR: Rate of change of trading volume of consumer industry, FiR: Rate of change of trading volume of financial industry, BaR: Rate of change of trading volume of banking industry, InR: Rate of change of trading volume of production industry, MaR: Rate of change of trading volume of raw material industry, UtR: Rate of change of trading volume of petroleum and natural gas industry, TeR: Rate of change of trading volume of information technology service industry, MeR: Rate of change of trading volume of medical nursing industry

Source: HOSTC (2016) 
Table 5. Descriptive statistics of Hanoi

\begin{tabular}{|l|l|l|l|l|}
\hline & Mas. & Min. & Avg. & SDV. \\
\hline HNXR & 4.7825 & -0.8113 & 0.4530 & 0.3365 \\
\hline CoR & 13.2503 & -0.9084 & 0.1040 & 0.5797 \\
\hline FiR & 11.0561 & -0.9545 & 0.0882 & 0.5905 \\
\hline BaR & 18.3672 & -0.9388 & 0.3315 & 1.4006 \\
\hline InR & 12.1197 & -0.9129 & 0.0675 & 0.4757 \\
\hline MaR & 156.4821 & -3.0243 & 0.2430 & 4.5417 \\
\hline UtR & 11.0683 & -0.9361 & 0.1252 & 0.6373 \\
\hline TeR & 84.5401 & -0.9870 & 0.3839 & 2.8911 \\
\hline MeR & 953.5864 & -0.9979 & 1.7292 & 20.7150 \\
\hline
\end{tabular}

Note: HNXR: Rate of change of trading volume of Hanoi City, CoR: Rate of change of trading volume of consumer industry, FiR: Rate of change of trading volume of financial industry, BaR: Rate of change of trading volume of banking industry, InR: Rate of change of trading volume of production industry, MaR: Rate of change of trading volume of raw material industry, UtR: Rate of change of trading volume of petroleum and natural gas industry, TeR: Rate of change of trading volume of information technology service industry, MeR: Rate of change of trading volume of medical nursing industry.

Source: HNX (2019)

\subsection{Collinearity}

Anderson, Sweeney, Williams (2014) stated that collinearity meant correlation existed among independent variables in multiple regression, when there was high correlation among independent variables, not only the regression coefficient will tend to be inaccurate, but also the regression coefficient will get distorted due to mutual influence among independent variables. Scholars such as Grewal et al. (2004) thought that the standard of collinearity should be below 0.95, and Cooper and Schindler (2003) pointed out that the standard of collinearity should be below 0.8 , in this study, in order to pursue the research accuracy, stricter standard has been adopted, and 0.8 was used to judge if collinearity existed among independent variable. Suppose the value of collinearity test result exceeded 0.8 , then in this study, variance inflation factor (VIF) will be further tested so as to see if VIF was significantly larger than 10 . If the VIF of one independent variable was larger than 10 , then collinearity was judged to exist among stocks, and in empirical analysis, it will not be adopted, in table 4 and table 5, all the collinearity values were tested to be lower than 0.8 , therefore, no VIF tests needed to be conducted. From Table 6, it can be seen that the maximal value of collinearity appeared in between raw material industry stock and production industry, and its value was lower than the standard0.8, then table 7 showed that in between production industry and consumer industry, the value was always lower than the standard of 0.8 . 
Table 6. Collinearity of Ho Chih Minh

\begin{tabular}{|l|l|l|l|l|l|l|l|l|}
\hline & CoR & FiR & BaR & InR & MaR & UtR & TeR & MeR \\
\hline CoR & 1.000 & & & & & & & \\
\hline FiR & 0.317 & 1.000 & & & & & & \\
\hline BaR & 0.149 & 0.147 & 1.000 & & & & & \\
\hline InR & 0.323 & 0.327 & 0.099 & 1.000 & & & & \\
\hline MaR & 0.335 & 0.377 & 0.139 & 0.407 & 1.000 & & & \\
\hline UtR & 0.174 & 0.144 & 0.102 & 0.128 & 0.180 & 1.000 & & \\
\hline TeR & 0.087 & 0.222 & 0.087 & 0.129 & 0.165 & 0.023 & 1.000 & \\
\hline MeR & 0.073 & 0.067 & 0.045 & 0.100 & 0.054 & 0.038 & 0.013 & 1.000 \\
\hline
\end{tabular}

Note: CoR: Rate of change of trading volume of consumer industry, FiR: Rate of change of trading volume of financial industry, BaR: Rate of change of trading volume of banking industry, InR: Rate of change of trading volume of production industry, MaR: Rate of change of trading volume of raw material industry, UtR: Rate of change of trading volume of petroleum and natural gas industry, TeR: Rate of change of trading volume of information technology service industry, MeR: Rate of change of trading volume of medical nursing industry.

Source: HOSTC (2016)

Table 7. Collinearity of Hanoi

\begin{tabular}{|l|l|l|l|l|l|l|l|l|}
\hline & CoR & FiR & BaR & InR & MaR & UtR & TeR & MeR \\
\hline CoR & 1.000 & & & & & & & \\
\hline FiR & 0.200 & 1.000 & & & & & & \\
\hline BaR & 0.136 & 0.138 & 1.000 & & & & & \\
\hline InR & 0.445 & 0.251 & 0.177 & 1.000 & & & & \\
\hline MaR & 0.043 & 0.097 & 0.042 & 0.067 & 1.000 & & & \\
\hline UtR & 0.311 & 0.180 & 0.134 & 0.419 & 0.062 & 1.000 & & \\
\hline TeR & 0.055 & 0.083 & 0.019 & 0.095 & 0.035 & 0.076 & 1.000 & \\
\hline MeR & 0.055 & 0.009 & 0.026 & 0.080 & 0.000 & 0.050 & -0.001 & 1.000 \\
\hline
\end{tabular}

Note: CoR: Rate of change of trading volume of consumer industry, FiR: Rate of change of trading volume of financial industry, BaR: Rate of change of trading volume of banking industry, InR: Rate of change of trading volume of production industry, MaR: Rate of change of trading volume of raw material industry, UtR: Rate of change of trading volume of petroleum and natural gas industry, TeR: Rate of change of trading volume of information technology service industry, MeR: Rate of change of trading volume of medical nursing industry.

Source: HNX (2019)

\subsection{Empirical results}

Table 8 showed a test of the significant performance of different industrial stocks in stock market of Ho Chih Minh, the results showed that consumer industry (Co), financial industry (Fi), banking industry $(\mathrm{Ba})$, production industry $(\mathrm{In})$, raw material industry $(\mathrm{Ma})$, petroleum and natural gas industry (Ut), information technology service industry (Te) were all of very significant, and only medical nursing industry (Me) was not significant. This meant that at the present stage, it was not appropriate to enter Ho Chih Minh market of Vietnam for medical nursing industry. 
Table 8. Significant performance of different industrial stock of Ho Chih Minh

\begin{tabular}{|c|c|c|c|c|c|c|c|c|}
\hline & CoR & FiR & BaR & InR & MaR & UtR & TeR & MeR \\
\hline & $\begin{array}{c}0.179 * * * \\
(0.009)\end{array}$ & $\begin{array}{c}0.204 * * * \\
(0.008)\end{array}$ & $\begin{array}{c}0.101^{* * *} \\
(0.002)\end{array}$ & $\begin{array}{c}0.146^{* * *} \\
(0.011)\end{array}$ & $\begin{array}{c}0.215^{* * *} \\
(0.011)\end{array}$ & $\begin{array}{c}0.031^{* * *} \\
(0.004)\end{array}$ & $\begin{array}{c}0.006^{* * *} \\
(0.002)\end{array}$ & $\begin{array}{c}0.001 \\
(0.002)\end{array}$ \\
\hline obs & \multicolumn{7}{|c|}{2675} \\
\hline R-square & \multicolumn{7}{|c|}{0.762} \\
\hline
\end{tabular}

Note $^{1}$ : CoR: Rate of change of trading volume of consumer industry, FiR: Rate of change of trading volume of financial industry, BaR: Rate of change of trading volume of banking industry, InR: Rate of change of trading volume of production industry, MaR: Rate of change of trading volume of raw material industry, UtR: Rate of change of trading volume of petroleum and natural gas industry, TeR: Rate of change of trading volume of information technology service industry, MeR: Rate of change of trading volume of medical nursing industry

Note $^{2}$ : Dependent variable was the rate of change of daily stock index, *,**,*** represented $10 \%$, $5 \%, 1 \%$ significance level.

Note $^{3}$ : Research period was from Jan. 052009 to October 012019.

Source: HOSTC (2016)

Table 9 showed a test of the significant performance of different industrial stocks in stock market of Hanoi, the results showed that consumer industry (Co), financial industry ( $\mathrm{Fi})$, banking industry $(\mathrm{Ba})$, production industry (In), petroleum and natural gas industry (Ut), information technology service industry (Te) were all of very significant, however, raw material industry (Ma) and medical nursing industry $(\mathrm{Me})$ were all of not significant.

Table 9. Significant performance of day effect of different industrial stocks in Hanoi

\begin{tabular}{|c|l|l|l|l|l|l|l|l|}
\hline & CoR & FiR & BaR & InR & MaR & UtR & TeR & MeR \\
\hline & $0.114 * * *$ & $0.0189 * * *$ & $0.078^{* * *}$ & $\begin{array}{l}0.294 * * * \\
(0.007)\end{array}$ & $\begin{array}{l}0.000 \\
(0.001)\end{array}$ & $\begin{array}{l}0.076^{* * *} \\
(0.005)\end{array}$ & $\begin{array}{l}0.002 * * \\
(0.001)\end{array}$ & -0.000 \\
& $(0.006)$ & $(0.005)$ & $(0.002)$ & $(0.000)$ \\
\hline obs & \multicolumn{70}{|c|}{0.813} \\
\hline R-square & \multicolumn{70}{|c|}{2675} \\
\hline
\end{tabular}

Note $^{1}$ : CoR: Rate of change of trading volume of consumer industry, FiR: Rate of change of trading volume of financial industry, BaR: Rate of change of trading volume of banking industry, InR: Rate of change of trading volume of production industry, MaR: Rate of change of trading volume of raw material industry, UtR: Rate of change of trading volume of petroleum and natural gas industry, TeR: Rate of change of trading volume of information technology service industry, MeR: Rate of change of trading volume of medical nursing industry.

Note $^{2}$ : Dependent variable was daily rate of change of stock index, $*$, **, *** represented $10 \%, 5 \%, 1 \%$ significance level.

Note $^{3}$ : Research period was from Jan. 052009 to October 012019

Source: HNX (2019)

\section{CONCLUSION}

According to empirical results, among different industries for listed companies in Vietnam, and for the significant performance of rate of change of trading volume of different stocks as shown in Tables 8 and 9, it can be seen that presently, it was not appropriate to enter Ho Chih Minh market and Hanoi market of Vietnam for medical nursing industry, and it was not significant for raw material industry in Hanoi market, for the rest of two stock markets, industrial stocks for consumer industry, financial industry, banking industry, production industry, petroleum and natural gas industry and information technology service industry were all significant. 
Table 10. Significant performance of rate of change of trading volume of eight major industrial stocks

\begin{tabular}{lcc}
\hline Industry Stock Market & Ho Chih Minh \\
\hline Consumer & $* * *$ & $* * *$ \\
Financial & $* * *$ & $* * *$ \\
Banking & $* * *$ & $* * *$ \\
Production & $* * *$ & $* * *$ \\
Raw Material & $* * *$ & \\
Petroleum and Natural & $* * *$ & $* * *$ \\
Gas & $* * *$ & $* *$ \\
IT Service & & \\
Medical Nursing & & \\
\hline
\end{tabular}

Source: HOSTC (2016) and HNX (2019)

In the stock market of Ho Chih Minh and the stock market of Hanoi, medical nursing industries were all not significant. Since Vietnam was a developing country, its economic and social development was less mature, therefore, Vietnam had less focus on the medical nursing industry. According to Ministry of Health and Welfare (2018), Vietnam's medical resource distribution was very uneven, and effective coordination and communication was usually insufficient, meanwhile, due to the citizen had high percentage of self-payment amount, the local citizen usually could not afford related medical expense, and this led to less focus on the medical nursing industry in Vietnam.

In the stock market of Hanoi, raw material industry was not significant. Because, in the economic flying stage, the negative effect of single structure of agriculture industry (Agricultural industry was classified into raw material industry) to the economic development of developing country was very significant, and such structure made its economy difficult to form equilibrium and harmonized self-development state, therefore, it has led to the retardation of industrialization process and industry upgrading. In the economic structure of Vietnam, its agricultural economy was still there, but in another aspect, its industrial economy was also developed, along with the deepening of industrialization, industrial structure was changed, therefore, presently, Vietnam put more focus on its industrial development. Taitra Global Trade Source (2019) showed the rise of quantity of major importing raw material product in Vietnam in the period of 2016 to 2018, it can be seen that Vietnam still relied very much on importing, and this led to the insignificant result of raw material industry.

The research results of this group showed that consumer industry, financial industry, banking industry, production industry, petroleum and natural gas industry and information technology service industry were markets that were appropriate to enter in Vietnam, however, for raw material industry, it was only appropriate to enter the market of Ho Chih Minh City, for medical nursing industry, it was not appropriate to enter Vietnam market. Hopefully, this research can provide information regarding industrial types that were appropriate to enter in Vietnam for Taiwan government and corporate related departments, and this research was also a response to Taiwan government's promotion of southbound policy. 


\section{REFERENCES}

Anderson, D. R., Sweeney, D. J., Williams, T. A., Camm, J. D. \& Cochran, J. J. (2014). Statistics for Business \& Economics (with XLSTAT Education Edition Printed Access Card). Boston: Nelson Education Ltd.

Bencivenga, V. R., Smith, B. D. \& Starr, R. M. (1995). Transactions costs, technological choice, and endogenous growth. Economic Theory, 67, 153-177.

Boubakari (2010). The Role of Stock Market Development in Economic Growth: Evidence from Some Euronext Countries. International Journal of Financial Research, 1(1), 1420.

Chang, C. C. (2009). The Investigation on the Relationship of Stock Prices for Electronic Industry in Taiwan. Journal of Chia Institute of Technology, 41, 211-225. DOI 10.7095/JCIT.200912.0211.

Chang, K. L. (2009). Study on the Relationship among Business Cycle, Macro Factors and TAIEX (Unpublished master dissertation, National Chiao Tung University, 2009). Retrieved From https://ndltd.ncl.edu.tw/cgi-bin/gs32/gsweb.cgi?o=dnclcdr\&s=id=\% 22098NCTU5303003\%22.\&searchmode=basic

Chou, P. F. (2016). Tsai Ing-wen, Xinnan Lane's Politics Eyes Low, Breaking China's Containment with Non-Politics. Retrieved September 01, 2016, from http://www.upmedia.mg/news_info.php?SerialNo=3399.

Cooper, D. R. \& Schindler, P. S. (2003). Business Research Methods (8th ed.). New York: McGraw-Hill Higher Education.

Dantri.com.vn (2009). 9 important economic events in Vietnam in 2009. Retrieved December 30, 2009, from http://sai-gon.blogspot.com/2009/12/20099.html.

Demirguc-Kunt, A., Levine, R., Demirguc-Kunt, A. \& Levine, R. (1996). Stock markets, corporate finance, and economic growth: an overview (English). The World Bank Economic Review. 10 (2), 223-239.

Grewal, R., Cote, J. A. \& Baumgartner, H. (2004). Multicollinearity and measurement error in structural equation models: Implications for theory testing. Marketing Science, 23(4), 519-529.

Hanoi Stock Exchange (2016). Retrieved from, https://hnx.vn/en-gb/.

Ho Chi Minh Securities Trading Center (2019). Retrieved from, https://www.hsx.vn/.

Kao, T. Y. (2005). Seminar on Southbound Policy. In Institute of Southeast Asian Studies. Retrieved September 7, 2010, from http://tkuir.lib.tku.edu.tw:8080/dspace/handle/ 987654321/50900.

$\mathrm{Ku}$, K. P. (2010). Sales Momentum Strategies. Journal of Management. 27(3), 267-289 DOI : 10.6504/JOM.2010.27.03.04.

Levine, R. (1991). Stock Markets, Growth and the Tax Policy. Journal of Finance, 46, 144565.

Levine, R. \& Zervos, S. (1996a). Stock Market Development and Long-Run Growth. The World Bank, Policy Research Working Paper No. 1582.

Liu, H. H. \& Tu, T. T. (2009). An Investigation on Volatility and the Interrelationship between the US Equity Market and Macroeconomic Variables - An Application of the VEC GJR DCC-GARCH-M Model. Taipei Economic Inquiry, 48 (1), 139-189. 
Mehl, A. (2009). The Yield Curve as a Predictor and Emerging Economies. Open Economies Review, 20(5), 683-716.

Ministry of Health and Welfare (2018). A new southward layout plan for the international healthcare. Retrieved December 28, 2018, from http://wwwfs.vghks.gov.tw/ Download.ashx?u=LzAwMS9WZ2hrc1VwbG9hZEZpbGVzLzM3OC9yZWxmaWxlLz AvMC91OGI0YWU2NS0zNmEwLTRmN2ItYjAxNC0wNjdmYzUxNjQ1MTUucGRm \&n=6LaK5Y2X6Yar6KGb5ZWG5oOF6LOH5paZ5bqrLnBkZg\%3D\%3D\&icon=.pdf.

NAiP (2018). A 15-year old Taiwanese business person puts it this way: investing in Vietnam is getting harder. Retrieved May 30, 2018, from http://www.naipo.com/Portals/1/web_ tw/Knowledge_Center/Editorial/IPNC_180530_1502.htm.

National Development Council (2010). Trends and strategies of mainland overseas investment and impact on Taiwan. Retrieved December, 2010, from https://ws.ndc.gov.tw/001/ administrator/10/relfile/5636/2355/0014716.pdf.

News release of People First Party (2016). "New Southbound" policy, "Four Dislikes" budget. Retrieved September 14, 2016, from https://media.gol.idv.tw/news-20160914-01.

Nowbutsing, B. M. \& Odit, M. P. (2009). Stock Market Development and Economic Growth: The Case of Mauritius. International Business \& Economics Research Journal, 8(2), 8688.

NOWNEWS (2018). Strong exports and expanding domestic demand ADB estimates Vietnam's GDP to grow by 7.1\%. Retrieved April 12, 2018, from https://www.nownews.com/news/20180412/2734296.

Schwert (1989). Why Does Stock Market Volatility Change Over Time? The Journal of Finance. XLIV (5), 1115-1153.

Su, X. Q., Lowe, A., Yuan, C. D. \& Yang, J. B. (2016). Stock Market Liquidity and the Business Cycle: Comprehensive Evidence from Taiwan. Journal of Management \& Systems. 23 (1), 65-106.

SWCW (2017). Vietnam's performance this year. Retrieved December 28, 2017, from http://www.swcw168.com.tw/news.aspx?ID=129794.

Taitra Global Trade Source (2011). Vietnam imported a total of USD 8.08 billion from Japan in the first 11 months of 2010. Retrieved January 25, 2011, from https://www.taitraesource.com/page03.asp?mag_id=43355\#.

Taiwan Chamber of Commerce (2017). Taking the South to the New Growth-Sharing Taiwanese Businessmen's Story of the New South at, Retrieved from December 28, 2018, 2017, from https://www.tcoc.org.tw/articles/20171108-479bfc24.

The World Bank (2019). Vietnam. From https://data.worldbank.org/country/vietnam.

Trading Economics (2020). Vietnam GDP. From https://tradingeconomics.com/vietnam/gdp.

vietnamplus.vn (2016). Vietnam Economic Annual Report 2016: target of 6.7\% growth this year is difficult to achieve. Retrieved from May 11, 2016 from .http://vietloan.blogspot.com/2016/05/201667.html

Wang, J. M. (2002). Chen Shui-bian's true intention of "southbound policy" and his reaction within the island. Retrieved August 15, 2002, from http://www.china.com.cn/chinese/OPc/189026.htm.

Wang, Y. H. (2014). Investing Strategies under the Stock Market Cycles-Evidences from TAIEX-listed Companies (Unpublished master dissertation, Chaoyang Univeristy of Technology, 2014). Retrieved from https://www.airitilibrary.com/Publication/ alDetailedMesh?docid=U0078-2611201410182326. 